\title{
Hydrochemical relationships at Meio Stream watershed, Leme, São Paulo
}

\author{
Fabiano Tomazini da Conceição ${ }^{1}$, Diego de Souza Sardinha ${ }^{2}$, Antonio Donizetti \\ Goncalves de Souza ${ }^{3}$ \& Daniel Marcos Bonotto ${ }^{2}$
}

\begin{abstract}
The evaluation of natural and anthropogenic contributions was performed for surface water from Meio Stream watershed at Leme city. Nine sampling points were chosen and the field campaigns were held in $02 / 25 / 2005,04 / 20 / 2005$ and $07 / 08 / 2005$, as this period comprises the more extreme seasonal variations in discharge from Meio Stream. The analyses were performed for $\mathrm{pH}$, temperature, turbidity, dissolved oxygen (DO), electrical conductivity (EC), TDS (total dissolved solids), TSS (total suspended solids), sulfate, nitrate, phosphate, alkalinity, chloride, sodium, calcium, potassium and magnesium. The chemical composition of unpolluted surface waters from Meio Stream watershed is dominated by weathering of rocks derived from São Bento and Passa Dois Group; the highest annual flux of cations/anions is derived from Constantino and Invernada creeks, that are water bodies situated in areas with mudstones and siltstones (Passa Dois Group). The Meio Stream, downstream from Leme city, receives several compounds through anthropogenic activities mainly related to the discharge of domestic effluents. A conceptual model considering the presence of dissolved oxygen indicates that the Meio Stream needs about $15 \mathrm{~km}$ downstream from its mouth to reach the minimum dissolved oxygen content $(5 \mathrm{mg} / \mathrm{L})$ allowed according to Brazilian standard related to Class 2 waters.
\end{abstract}

Keywords: watershed, water quality; water-rock interaction; anthopogenic influences; environmental management.

\begin{abstract}
Resumo Relações hidroquímicas na bacia hidrográfica do Ribeirão do Meio, Leme, São Paulo. A avaliação das contribuições naturais e antrópicas foi realizada para as águas superficiais da bacia hidrográfica do Ribeirão do Meio na cidade de Leme. Nove pontos de amostragem foram escolhidos e as campanhas de amostragem ocorreram em 25/02/2005, 20/04/2005 e 08/07//2005, sendo que esse período compreende a maior variação sazonal na vazão do Ribeirão do Meio. As analises foram executadas para $\mathrm{pH}$, temperatura, turbidez, oxigênio dissolvido (OD), condutividade elétrica (CE), SDT (sólidos dissolvidos totais), STS (sólidos totais em suspensão), sulfato, nitrato, fosfato, alcalinidade, cloreto, sódio, cálcio, potássio e magnésio. A composição química das águas superficiais não poluídas da bacia hidrográfica do Ribeirão do Meio é dominada pela alteração das rochas derivadas dos grupos São Bento e Passa Dois; o mais alto transporte específico anual de cátions/ânions é derivada dos Córregos Constantino e Invernada, que são corpos de água situados em áreas com argilitos e siltitos (Grupo Passa Dois). O Ribeirão do Meio, após a cidade de Leme, recebe diversos compostos através de atividades antropogênicas principalmente relatadas aos efluentes domésticos. Um modelo conceitual considerando a presença de oxigênio dissolvido indica que o Ribeirão do Meio precisa de aproximadamente 15 $\mathrm{km}$ após sua foz para alcançar a quantidade mínima de oxigênio dissolvido $(5 \mathrm{mg} / \mathrm{L})$ permitido de acordo com o padrão brasileiro para as águas de Classe 2 .
\end{abstract}

Palavras-chave: bacia hidrográfica, qualidade da água, interação água-rocha, influências antropogênicas, gerenciamento ambiental.

INTRODUCTION Recent data show that 1.7 billion people presently live without water with adequate quality; a number that may increase to 3.3 billion in 2020 and that may cause conflicts if effective water management is not realized. The water quality classification of rivers is usually established according to legal standards (Souza and Tundisi 2003) and it should be expected to be improved over time (Seager 1993, Barth 1999). In Brazil, the classification of water bodies was established by CONAMA (National Council for Environment) Rule $\mathrm{N}_{\mathrm{o}}$ 357, that defines freshwaters (special, 1, 2, 3 and 4 classes), brackish waters (special, 1,
2 and 3 classes) and saline waters (special, 1, 2 and 3 classes), depending on several water quality variable (CONAMA 2005).

The term "clean water" has been sometimes used to specify the state of water in which no substance is present in concentration to prevent the normal use of water (recreation and aesthetics, public water supply, fish and wildlife, agriculture and industry) (Stoker and Seager 1976). However, natural surface waters usually contain dissolved species derived from dry (aerosols) and wet deposition (rainwater) (Gibbs 1970, Stallard and Edmond, 1981) and from chemical weathering of rocks

1 - Department of Environmental Engineering, UNESP, Sorocaba, São Paulo, Brazil. E-mail: ftomazini@sorocaba.unesp.br

2 - Institute of Geosciences and Exact Sciences, UNESP, Rio Claro, S.P, Brazil. E-mail: sardinha@rc.unesp.br and dbonotto@rc.unesp.br

3 - Department of Environmental Engineering, Faculdades COC, Ribeirão Preto, São Paulo, Brazil. E-mail: donizetti@coc.com.br 
(water-rock interactions) (Garrels and MacKenzie 1967, Moreira-Nordemann 1980 and 1984). Additionally, the input of elements from non-weathering components (anthropogenic inputs) leads to important corrections to obtain the fraction coming from dissolved rocks (White and Blum 1995, Rose 2002, Joshi and Kotayari 2003, Dworkin 2003, Das 2005, Ahipathy and Puttaiah 2006). In Brazil, some studies have attempted to document the variation of the chemical composition on surface waters relative to natural or anthropogenic contributions (see, for instance, Moreira-Nordemann 1980 and 1984, Danelon and Moreira-Nordemann 1991, Souza and Tundisi 2003, Costa et al. 2003, Conceição and Bonotto 2002 and 2004).

Water pollution refers to degradation of water quality mainly due to domestic, agricultural and industrial wastes (Braga et al. 2002). The major pollutants may be classified in nine categories: oxygen-demanding wastes, disease-causing agents, plant nutrients, synthetic organic compounds, oil, inorganic sediments and mineral substances, sediments, radioactive materials and heat (Stoke and Seager 1976). In urban hydrographic basins, the oxygen-demanding wastes derived from domestic effluents are greatly responsible by water pollution, because the bacterial activity quickly leads to depletion of the oxygen levels in the water, so that fish and other organisms die (Keller 2000). Mathematical modeling has also been used to determine the changes in water quality due to domestic effluents (see, for instance, von Sperling 1996, Lima 2001). Streeter and Phelps (1925) firstly applied a mathematical modeling to Ohio River (USA) for evaluation the effect of biochemical oxygen demand (BOD) on dissolved oxygen (DO) content in order to identify the natural purification in a water body.

This paper reports the use of physical and chemical parameters related to water quality, in order to evaluate the natural and anthropogenic contributions on surface water from Meio Stream watershed at Leme city, São Paulo State, Brazil. The Meio Stream watershed was chosen because contains several springs located in areas exempt of environmental impacts, allowing the evaluation of natural contributions to surface waters due to water-rock interactions occurring among several stratigraphic units from the giant Paraná sedimentary basin (Paleozoic - Cenozoic), that covers about $70 \%$ of São Paulo State.

OVERVIEW OF THE MEIO STREAM WATERSHED The Meio Stream and tributaries (Constantino, Invernada, Jequitibá and Taquari creeks) extend over an area of about $252 \mathrm{~km}^{2}$ in the middle-east part of the São Paulo State (Fig. 1). It lies between $22^{\circ} 04^{\prime} 24^{\prime \prime}$ and $22^{\circ} 15^{\prime} 46^{\prime \prime} \mathrm{S}$ and $47^{\circ} 15^{\prime} 18^{\prime \prime}$ and $47^{\circ} 27^{\prime} 32^{\prime \prime}{ }^{\prime \prime} \mathrm{W}$, being about $300 \mathrm{~km}$ west of the Atlantic Ocean coast. The Meio Stream watershed occurs in an eroded belt in the cuestas zone of the "Depressão Periférica" geomorphological province (Penteado 1976). This province delimits the northeastern edge of the basaltic flows in the Paraná sedimentary basin and the crystalline plateau. Topographically, the region is a great plain, with maximum altitude of $788 \mathrm{~m}$ and minimum of $530 \mathrm{~m}$.

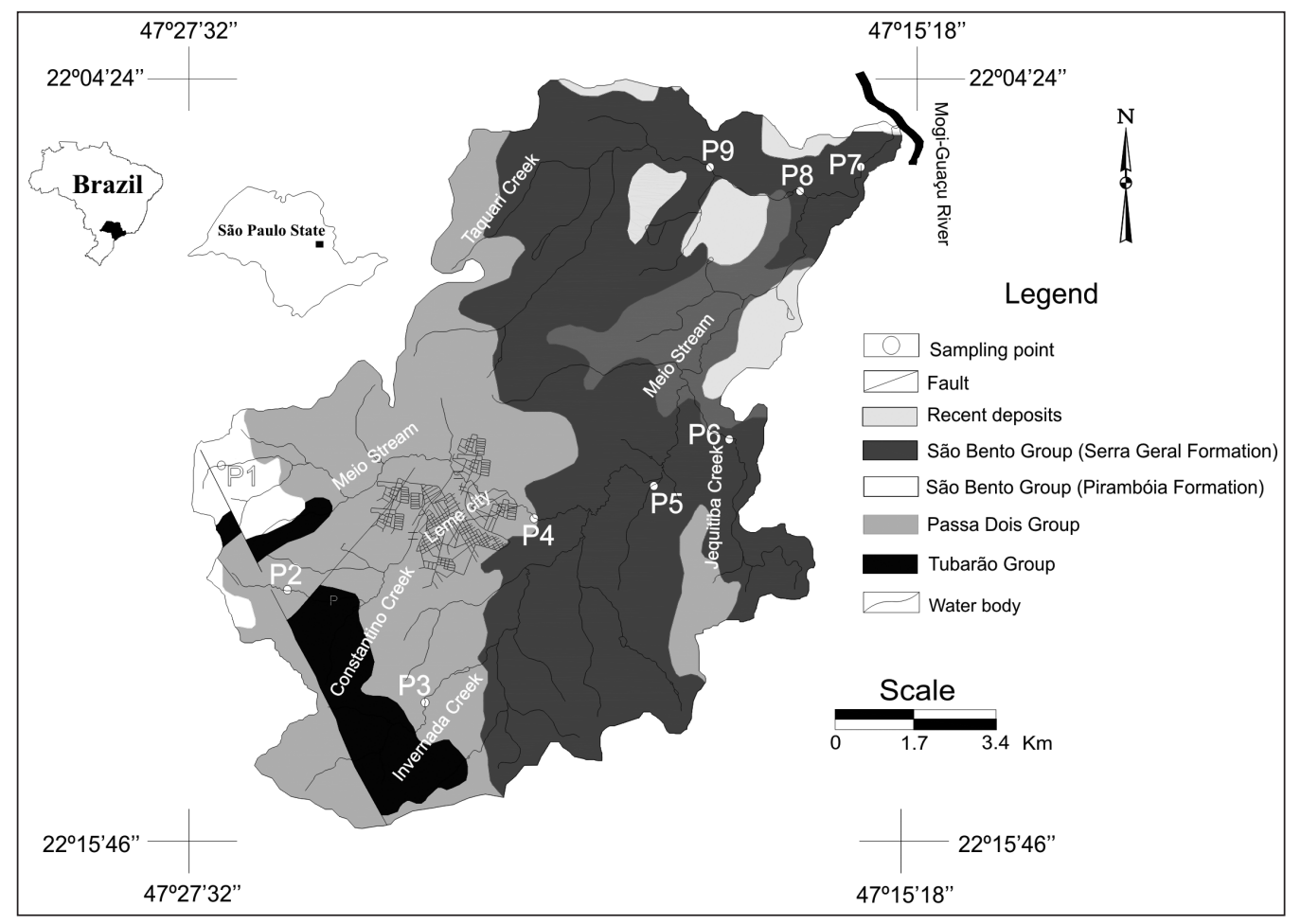

Figure 1 - The Meio Stream watershed geological map and location of the surface waters sampling points. P1, P4, P5, P7 and P8-Meio Stream; P2 -Constantino Creek; P3 -Invernada Creek; P6 - Jequitibá Creek; P9 -Taquari Creek. 
The Meio Stream and tributaries start flowing in the cuestas zone, reaching the Mogi-Guaçu River after crossing Leme city, the most important municipality in the basin, with 80,000 inhabitants (IBGE 2000).

The climate of the region is Aw type (Köeppen classification), i. e. tropical rainy weather characterized by wet summer (October through March) and dry winter (April through September); the mean temperature in almost all months is higher than $22.5^{\circ} \mathrm{C}$, reaching $30^{\circ} \mathrm{C}$ in the hottest one (December). In the area prevail tropical and equatorial air masses at least during 6 months each year and the winds predominantly have S-SE direction. The mean annual rainfall was $1,321 \mathrm{~mm}$ over the last 60 years (DAEE 2005) (Fig. 2). The original vegetation mainly consisted on wood and savanna in the past, it

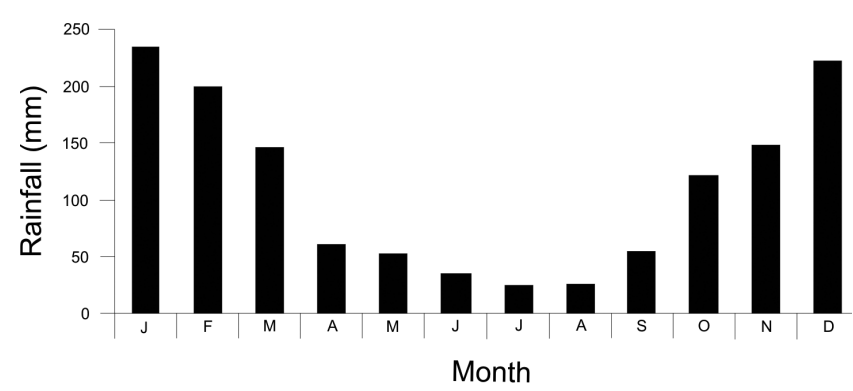

Figure 2 - Monthly average rainfall for a 60 years period (1945-2005) at Meio Stream watershed (DAEE, 2005).

was continuously substituted by other uses, so that the present land use is represented by pasture (51\%), sugar cane $(26 \%)$, urban area $(14 \%)$, orange crops $(5 \%)$ and natural vegetation $(4 \%)$.

The Meio Stream watershed is a sub-basin of the giant Paraná sedimentary basin that extends over an area of 1,600,000 $\mathrm{km}^{2}$, comprising southern Brazil $\left(1,000,000 \mathrm{~km}^{2}\right.$ in Brazilian surface), eastern Paraguay, northeastern Uruguay and northeastern Argentine. Several stratigraphic units of the intercratonic Paraná sedimentary basin crop-out in the Meio Stream watershed, including (IPT 1981, Almeida and Melo 1981) (Fig. 1): (a) Tubarão Group (Mean Permian to Upper Carboniferous): composed by arkosian sandstones, conglomerates, diamictites, tillites, siltstones, shales and rythmites; (b)Passa Dois Group (Upper Permian): gray/ fawnish/reddish mudstones, shales, siltstones with interbedded layers of fine sandstones and layers of oolitic limestones; (c) São Bento Group (Lower Cretaceous to Triassic): Pirambóia (reddish fine fluvial silt/clayey sandstones, layers of shales and variegated coloured clayey sandstones) and Serra Geral formations (gray to black basalts with interbedded fine sandstones and diabases sills); (d) Different types of recent deposits composed by fine to mean unconsolidated sandstones, mudstones and limited presence of conglomerates.

According to USDA (1999) and EMBRAPA (1999) nomenclatures, the major soil types occurring in the Meio Stream watershed are Ultisols (Argissolos) and Oxisols (Latossolos), which cover about $90 \%$ of the basin area. The Ultisols are represented by Kandiudults (Argissolo Vermelho Distrófico) and Rhodic Kandiudults (Argissolo Vermelho-escuro) - soils with textural B horizon and low cation exchange capacity. The Oxisols are sub-divided into three different types: Rhodic Kandiudox (Latossolo Vermelho Distrófico) - soil derived from basic rocks, with oxic $\mathrm{B}$ horizon and considerably high $\mathrm{Fe}_{2} \mathrm{O}_{3}$ content (18-40\%); Xanthic Kandiudox (Latossolo Vermelho-escuro) - soil with oxic B horizon and presence of $\mathrm{Fe}_{2} \mathrm{O}_{3}(18 \%)$; Humic Hapludox (Latossolo vermelho-amarelo) - soil with oxic $\mathrm{B}$ horizon and presence of $\mathrm{Fe}_{2} \mathrm{O}_{3}$ between 7 and $11 \%$. Oliveira et al. (1982) also describe two additional soil types: Entisols (Gleissolo) - hydromorphic soil lower than $120 \mathrm{~cm}$ deep and Quartzipsamment (Neossolo Quartzoarênico) - very friable soil with sandy grain size along the profile.

MATERIALS AND METHODS A visual evaluation of the anthropogenic influences occurring at Meio Stream watershed was initially realized, which allowed identifying their impacts on the surface waters quality. Then, nine sampling points were chosen for surface water sampling, which was conducted in 25 February 2005, 20 April 2005 and 8 July 2005 (Fig. 1). Such period was selected as it involves the more extreme variations in rainfall (see in Fig. 2 the minimum values in July-August and the maximum ones in January-February), and, consequently, in the discharge of the Meio Stream. The sites P1 (Meio Stream, close to spring), P2 (Constantino Creek), P3 (Invernada Creek), P6 (Jequitibá Creek) and P9 (Taquari Creek) are located in a region distant from environmental impacts; the sites P4, P5 and P8 (Meio Stream) are located downstream from Leme city; the monitoring point P7 (Meio Stream) is situated near the mouth of Meio Stream at the confluence with the MogiGuaçu River. The discharge of all sampling points was estimated according to the float method by equation:

$$
Q=\frac{A \cdot D \cdot C}{T}
$$

$$
\begin{aligned}
& \text { Where: } \\
& Q=\text { discharge }\left(\mathrm{m}^{3} / \mathrm{s}\right) ; A=\text { cross section of the river } \\
& \left(\mathrm{m}^{2}\right) ; D=\text { distance to estimate the water speed in } \\
& \text { the river }(\mathrm{m}) ; C=\text { empirical coefficient }(0.9) ; T= \\
& \text { time for the floating body travel through the dis- } \\
& \text { tance D }(\mathrm{s}) \text {. }
\end{aligned}
$$

The surface water samples were collected for hydrochemical analyses and each one was divided into three aliquots and stored in polyethylene bottles under different conditions: (a) Raw surface water was used for $\mathrm{pH}$, temperature, turbidity, dissolved oxygen (DO), electrical conductivity (EC), TDS (total dissolved solids) and TSS (total suspended solids) measurements. The $\mathrm{pH}$, temperature, turbidity, dissolved oxy- 
gen and electrical conductivity were measured in the field through the potentiometry methods. TDS and TSS were measured through the gravimetric method (APHA 1995); (b) Filtered surface water $(0.45 \mu \mathrm{m}$ Millipore membrane) was used for sulfate, nitrate, phosphate, alkalinity and chloride determinations. Sulfate (barium sulfate colorimetric method; range: 0 to $70 \pm 0.9 \mathrm{mg} / \mathrm{L}$ ), phosphate (cadmium reduction method; range: 0 to 3 $\pm 0.01 \mathrm{mg} / \mathrm{L}$ ) and nitrate (cadmium reduction method; range: 0 to $20 \pm 0.4 \mathrm{mg} / \mathrm{L}$ ) were measured by a Hach DR 2000 spectrophotometer (Hach 1992). Alkalinity was measured by titration with $0.02 \mathrm{~N}$ sulfuric acid (Hach 1992) in the range of 1 to $500 \pm 0.2 \mathrm{mg} / \mathrm{L}$ and chloride $(0.1$ to $100 \pm 0.02 \mathrm{mg} / \mathrm{L})$ was evaluated by potentiometry; (c) Filtered and acidified water $\left(\mathrm{HNO}_{3}\right.$, $\mathrm{pH}<2$ ) was used for dissolved sodium, calcium, potassium and magnesium determinations, being these analyses realized by atomic absorption spectrometry (AAS).

\section{RESULTS AND DISCUSSION}

Surface waters quality from Meio Stream watershed

Table 1 and figure 3 present the physical and chemical parameters for all surface waters samples from Meio Stream watershed. The weighed mean to cations/anions concentration was calculated by the following formula:

$$
C_{E}=\frac{\sum_{i=1}^{n} C_{i} \cdot V_{i}}{\sum_{i=1}^{n} V_{i}}
$$

\section{Where:}

$C_{E}=$ weighed mean element concentration; $C_{i}=$ Element concentration for the i - th measurement; $V_{i}=$ flow of the river in the day of the $\mathrm{i}-$ th measurement.

The discharge in all sampling points was higher in wet summer than in dry winter. The variation of water temperature followed seasonal trends, as expected, with lower value (average $=19{ }^{\circ} \mathrm{C}$ ) in winter and higher value (average $=26^{\circ} \mathrm{C}$ ) in summer. The $\mathrm{pH}$ is governed by the carbonate-bicarbonate-carbon dioxide equilibrium and can alter the permeability process of the cellular membrane (Esteves 1988). The $\mathrm{pH}$ values obtained during the sampling period were close to neutral or slightly alkaline, with the highest value being measured in Meio Stream (7.9 - P7) in February 2005, and the lowest one in Constantino Creek (6.8 - P2) in July 2005. Suspended colloidal particles and dissolved materials are responsible by turbidity in natural waters. The turbidity values were always lower than the maximum permissible limit (100 TU) for freshwaters belonging to Class 2 , i. e. freshwaters with salinity equal or lower than $0.50 \%$ and that are appropriate for domestic users after conventional treatment (CONAMA
2005).

The electrical conductivity (EC) allows to quantify the macronutrients, identify sources of pollution, and obtain information about primary production and decomposition (Porto 1991). The lower EC values were obtained at Taquari Creek (P9) and highest at Meio Stream (P4, P5, P7 and P8) downstream from Leme city. The weathering of rocks may increase the electrical conductivity, but the increase of this parameter after Leme city must be attributed principally to domestic wastes. The inorganic salts, silica and soluble organic matter are responsible by total dissolved solids (TDS) on surface waters (Esteves 1988). The TDS values obtained at Meio Stream do not significantly differ during the dry winter and wet summer. However, lower TDS values have been reported in other watersheds due to dilution caused by rainwater in wet summer (MogiGuaçu River basin - Maier 1977; Corumbataí River basin - Conceição and Bonotto 2002; Jaboatão River basin - Souza and Tundisi 2003).

According to CONAMA (2005), the results obtained for major anions suggest that the analyzed waters belong to Class 2 . Bicarbonate alkalinity was predominant in all sampling points and the highest concentrations of alkalinity, chloride, sulfate and sodium were obtained at Meio Stream (P4) downstream from Leme city, possibly related to discharge of domestic wastes. The highest values for calcium were found in Constantino and Invernada Creek. Phosphorous is a fundamental element to metabolism of humans and nitrate is found in waters due to oxidation of compounds containing nitrogen in their composition (Esteves 1988). Some sampling points possess high nitrate values, however, they are lower than the maximum permissible concentration limit (10 mg/L) to Class 2 (CONAMA 2005). The phosphate concentration in most of the samples was higher than the maximum permissible concentration limit $(0.10 \mathrm{mg} / \mathrm{L})$ to Class 2 (CONAMA 2005). Excess of nutrients due to these anthropogenic inputs as well have been suggested to be the major source responsible for increased eutrophication of water reservoirs (Nogueira 1991, Conceição and Bonotto 2002, Souza and Tundisi 2003). Esteves (1988) describes many problems caused by euthrophication, such as increase of aquatic plants (particularly algae) and decrease of oxygen content, which cause the death of fish and aquatic animals and unpleasant taste and odor to surface waters.

In relation to dissolved oxygen, its concentration on surface waters depends on physical, chemical and biological processes; the atmosphere and the photosynthesis are their principal sources, whereas the decomposition of organic matter, diffusion to atmosphere and respiration of aquatic organisms are responsible by decrease of its concentration (Esteves 1988). The dissolved oxygen values in Meio Stream (P4, P5, P7 and P8) downstream from Leme city are lower than those at other sampling points, as well lower than the maximum permissible limit $(5 \mathrm{mg} / \mathrm{L})$ for freshwaters belonging to Class 2 (CONAMA 2005) (Fig. 4). Such low values are certainly related to the discharge of domestic wastes 
Table 1 - Physical and chemical parameters for surface waters from Meio Stream watershed.

\begin{tabular}{c|c|c|c|c|c|c|c|c|c|c|c|c|c|c|c|c|c}
\hline Sampling & Discharge & EC & Temp & pH & Turb. & DO & TDS & TSS & $\mathrm{Ca}^{2+}$ & $\mathrm{Mg}^{2+}$ & $\mathrm{Na}^{+}$ & $\mathrm{K}^{+}$ & $\mathrm{HCO}_{3}^{-}$ & $\mathrm{Cl}^{-}$ & $\mathrm{PO}_{4}^{3-}$ & $\mathrm{SO}_{4}^{2-}$ & $\mathrm{NO}_{3}^{-}$ \\
\hline Point & $\left(\mathrm{m}^{3} / \mathrm{s}\right)$ & $(\mu \mathrm{S} / \mathrm{cm})$ & $\left({ }^{\circ} \mathrm{C}\right)$ & & $(\mathrm{TU})$ & \multicolumn{1}{c}{$(\mathrm{mg} / \mathrm{L})$} \\
\hline
\end{tabular}

\begin{tabular}{c|c|c|c|c|c|c|c|c|c|c|c|c|c|c|c|c|c}
\hline \multicolumn{10}{c}{ Sampling date: 25 February 2005} \\
\hline $\mathrm{P}^{1}$ & 0.030 & 25 & 23 & 7.5 & 3 & 6.7 & 272 & 28 & 7.0 & 0.5 & 2.6 & 2.6 & 12 & 7.8 & 0.57 & 3 & 2.2 \\
\hline $\mathrm{P}^{2}$ & 0.043 & 165 & 26 & 7.4 & 1 & 5.9 & 454 & 26 & 17.0 & 3.6 & 9.4 & 5.2 & 56 & 26.6 & 0.75 & 9 & 3.3 \\
\hline $\mathrm{P}^{3}$ & 0.095 & 118 & 28 & 7.6 & 11 & 5.6 & 628 & 32 & 14.6 & 2.6 & 5.5 & 2.8 & 49 & 21.1 & 0.52 & 7 & 2.8 \\
\hline $\mathrm{P}^{1}$ & 0.336 & 178 & 29 & 7.3 & 9 & 1.7 & 398 & 28 & 12.0 & 2.2 & 13.6 & 3.9 & 56 & 47.3 & 1.23 & 10 & 5.0 \\
\hline $\mathrm{P}^{1}$ & 0.860 & 138 & 27 & 7.2 & 5 & 1.2 & 430 & 30 & 9.8 & 2.3 & 9.4 & 2.6 & 46 & 23.7 & 0.87 & 8 & 4.4 \\
\hline $\mathrm{P}^{4}$ & 0.068 & 60 & 25 & 7.6 & 1 & 5.7 & 202 & 18 & 10.0 & 0.4 & 2.9 & 0.7 & 28 & 14.1 & 0.39 & 1 & 0.9 \\
\hline $\mathrm{P}^{1}$ & 1.625 & 93 & 25 & 7.9 & 6 & 3.3 & 506 & 22 & 8.0 & 5.8 & 7.5 & 2.2 & 32 & 12.6 & 0.60 & 4 & 2.5 \\
\hline $\mathrm{P}^{1}$ & 1.270 & 108 & 25 & 7.1 & 7 & 1.9 & 378 & 34 & 9.0 & 1.9 & 8.4 & 2.6 & 36 & 11.2 & 0.92 & 5 & 3.2 \\
\hline $\mathrm{P}^{5}$ & 0.330 & 23 & 24 & 7.6 & 28 & 5.4 & 354 & 46 & 5.0 & 2.3 & 2.8 & 1.6 & 16 & 2.2 & 0.09 & 0 & 1.1 \\
\hline
\end{tabular}

Sampling date: 20 April 2005

\begin{tabular}{c|c|c|c|c|c|c|c|c|c|c|c|c|c|c|c|c|c}
\hline $\mathrm{P}^{1}$ & 0.007 & 20 & 27 & 7.3 & 15 & 6.5 & 302 & 18 & 3.6 & 0.6 & 2.5 & 2.2 & 13 & 6.0 & 0.05 & 0 & 1.8 \\
\hline $\mathrm{P}^{2}$ & 0.033 & 150 & 30 & 6.9 & 7 & 5.4 & 148 & 12 & 14.4 & 6.0 & 9.5 & 5.1 & 65 & 14.1 & 0.07 & 8 & 3.1 \\
\hline $\mathrm{P}^{3}$ & 0.073 & 110 & 31 & 7.2 & 16 & 5.8 & 416 & 24 & 11.0 & 5.8 & 5.7 & 2.3 & 56 & 8.0 & 0.04 & 3 & 2.2 \\
\hline $\mathrm{P}^{1}$ & 0.260 & 190 & 28 & 6.9 & 10 & 1.5 & 113 & 27 & 9.0 & 4.2 & 21.2 & 5.3 & 74 & 22.4 & 1.07 & 11 & 8.8 \\
\hline $\mathrm{P}^{1}$ & 0.670 & 100 & 26 & 6.9 & 11 & 2.1 & 268 & 12 & 7.0 & 2.3 & 8.9 & 2.3 & 49 & 11.2 & 0.32 & 3 & 7.9 \\
\hline $\mathrm{P}^{4}$ & 0.049 & 50 & 26 & 7.3 & 4 & 7.3 & 96 & 4 & 7.0 & 2.3 & 2.4 & 0.4 & 32 & 3.8 & 0.06 & 0 & 0.4 \\
\hline $\mathrm{P}^{1}$ & 1.248 & 80 & 25 & 6.9 & 8 & 4.2 & 632 & 8 & 4.6 & 3.3 & 12.7 & 3.3 & 37 & 6.0 & 0.15 & 2 & 3.1 \\
\hline $\mathrm{P}^{1}$ & 0.980 & 100 & 25 & 6.9 & 12 & 3.3 & 286 & 14 & 6.6 & 2.5 & 10.9 & 2.7 & 44 & 8.9 & 0.13 & 4 & 5.7 \\
\hline $\mathrm{P}^{5}$ & 0.256 & 20 & 29 & 7.2 & 16 & 6.2 & 220 & 20 & 3.4 & 1.0 & 2.5 & 1.7 & 18 & 1.9 & 0.04 & 0 & 0.9 \\
\hline
\end{tabular}

Sampling date: 8 July 2005

\begin{tabular}{c|c|c|c|c|c|c|c|c|c|c|c|c|c|c|c|c|c}
\hline $\mathrm{P}^{1}$ & 0.006 & 220 & 21 & 6.9 & 16 & 7.2 & 456 & 14 & 4.0 & 0.5 & 3.8 & 4.4 & 9 & 11.5 & 0.34 & 0 & 2.2 \\
\hline $\mathrm{P}^{2}$ & 0.026 & 160 & 21 & 6.8 & 1 & 6.1 & 352 & 8 & 14.4 & 3.6 & 16.6 & 10.4 & 52 & 26.5 & 0.22 & 9 & 3.5 \\
\hline $\mathrm{P}^{3}$ & 0.058 & 100 & 18 & 7.4 & 10 & 7.8 & 502 & 18 & 11.2 & 3.8 & 8.0 & 6.5 & 40 & 24.2 & 0.29 & 6 & 2.6 \\
\hline $\mathrm{P}^{1}$ & 0.210 & 230 & 20 & 7.0 & 34 & 1.4 & 405 & 55 & 8.0 & 1.7 & 21.2 & 7.6 & 71 & 50.5 & 2.75 & 16 & 2.2 \\
\hline $\mathrm{P}^{1}$ & 0.530 & 130 & 18 & 7.0 & 14 & 2.4 & 358 & 22 & 8.0 & 1.0 & 11.4 & 2.9 & 43 & 26.5 & 0.35 & 7 & 1.3 \\
\hline $\mathrm{P}^{4}$ & 0.045 & 30 & 21 & 7.7 & 1 & 7.2 & 292 & 8 & 5.0 & 2.2 & 3.8 & 0.4 & 22 & 12.6 & 0.07 & 0 & 0.4 \\
\hline $\mathrm{P}^{1}$ & 0.997 & 110 & 18 & 7.1 & 8 & 4.1 & 534 & 26 & 6.4 & 1.9 & 6.7 & 2.4 & 37 & 16.6 & 0.41 & 7 & 0.4 \\
\hline $\mathrm{P}^{1}$ & 0.780 & 110 & 18 & 7.0 & 19 & 3.0 & 382 & 18 & 6.2 & 1.9 & 16.7 & 4.9 & 44 & 12.4 & 0.63 & 6 & 0.9 \\
\hline $\mathrm{P}^{5}$ & 0.210 & 10 & 19 & 7.2 & 13 & 8.2 & 326 & 14 & 3.6 & 0.5 & 4.3 & 1.2 & 12 & 3.5 & 0.03 & 0 & 0.9 \\
\hline
\end{tabular}

${ }^{1} \mathrm{P} 1, \mathrm{P} 4, \mathrm{P} 5, \mathrm{P} 7$ and P8 - Meio Stream; ${ }^{2} \mathrm{P} 2$ - Constantino Creek;

${ }^{3} \mathrm{P} 3$ - Invernada Creek; ${ }^{4} \mathrm{P} 6$ - Jequitibá Creek; ${ }^{5} \mathrm{P} 9$ - Taquari Creek.

from Leme city, and the simple conceptual model (Streeter and Phelps 1925) in figure 4 could represent the situation in the area studied.

The Meio Stream upstream from Leme city (P1) is situated in a clean water zone. The pollution zone would be occurring downstream from Leme city, being characterized by a decreased of life species, high BOD content and elevated consume of dissolved oxygen by microorganisms. After the pollution zone, the
Meio Stream (P4 and P5) would reach an active decomposition zone (low dissolved oxygen values). Then, the Meio Stream (P7 and P8) would enter a recovery zone $15 \mathrm{~km}$ distant from Leme city, characterized by a dissolved oxygen increase and BOD content decrease, as most of the oxygen-demanding organic waste would have decomposed. Such conceptual model suggests the need of settling a wastewater treatment plant in order to reduce the amount of oxygen-demanding materials 

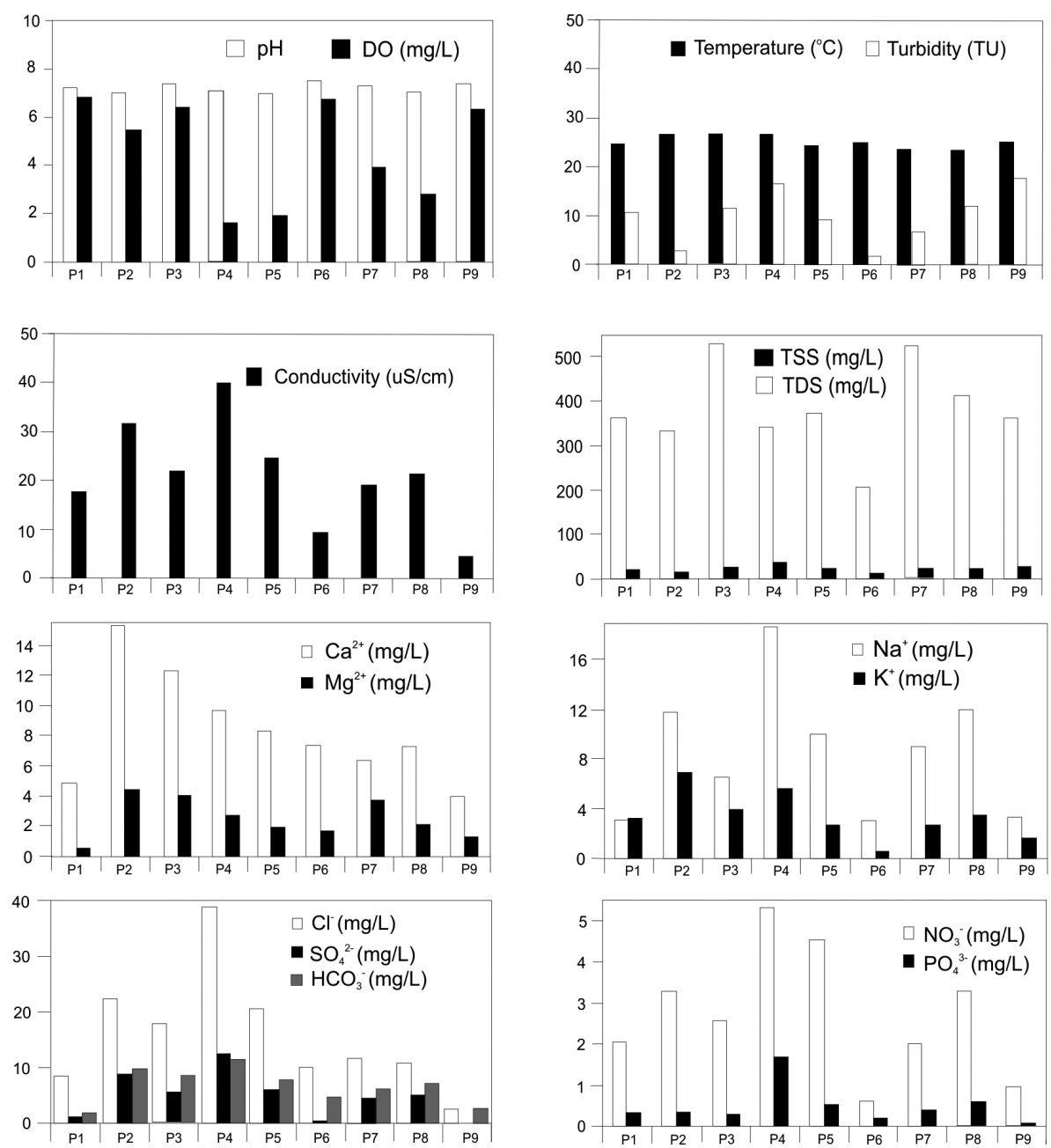

Figure 3 - Arithmetic mean for $\mathrm{pH}$, temperature, conductivity, turbidity, dissolved oxygen (DO), total dissolved solids (TDS) and total suspended solids (TSS) and weighed mean for $\mathrm{Ca}^{2+}, \mathrm{Mg}^{2+}, \mathrm{Na}^{+}, \mathrm{K}^{+}, \mathrm{Cl}^{-} \mathrm{SO}_{4}^{2-}, \mathrm{NO}_{3}^{-}, \mathrm{HCO}_{3}^{-}$and $\mathrm{PO}_{4}^{3-}$ in surface waters from Meio Stream watershed. P1, P4, P5, P7 and P8 - Meio Stream; P2 - Constantino Creek; P3 - Invernada Creek; P6 - Jequitibá Creek; P9 - Taquari Creek.

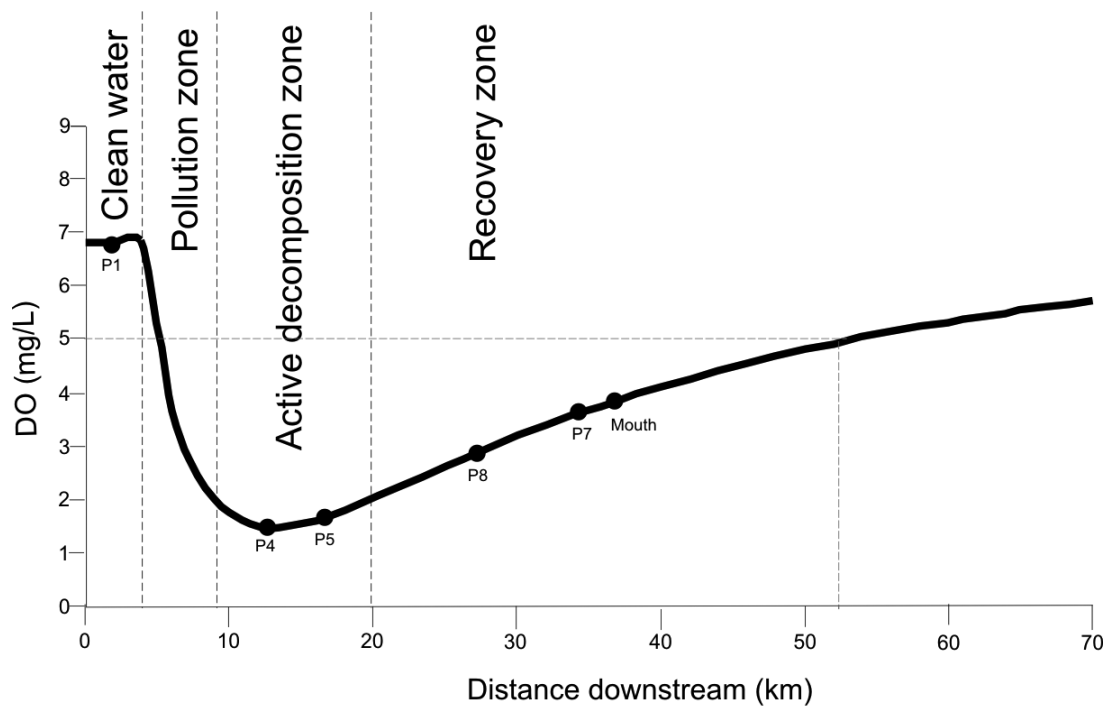

Figure 4 - Conceptual model of natural purification (Streeter and Phelps, 1925) for surface waters from Meio Stream. P1, P4, P5, P7 and P8 Meio Stream. 
in wastewater derived from Leme city. If Leme city had a primary wastewater treatment plant (30-40\% efficient), then, the dissolved oxygen concentration at Meio Stream would still be lower than $5 \mathrm{mg} / \mathrm{L}$, being necessary the installation of a secondary wastewater treatment at least $65 \%$ efficient in order to raise the dissolved oxygen content up to values higher than $5 \mathrm{mg} / \mathrm{L}$ (Fig. 4).

\section{Surface waters classification from Meio Stream wa-} tershed Soft water can be related to waters with low concentrations of these cations and various studies worldwide (United States, Wales, England, Sweden and Japan) concluded that communities with relatively harder water have a lower rate of heart disease than communities with soft water (Keller 2000). All surface water samples from Meio Stream watershed are classified as soft waters (Sawyer and McCarty 2000).

When the weighed mean data for cations and anions (in $\mathrm{meq} / \mathrm{L}$ ) for the surface waters from Meio Stream watershed are plotted on a partial standard Piper (1944) diagram (Fig. 5), it is possible verify different
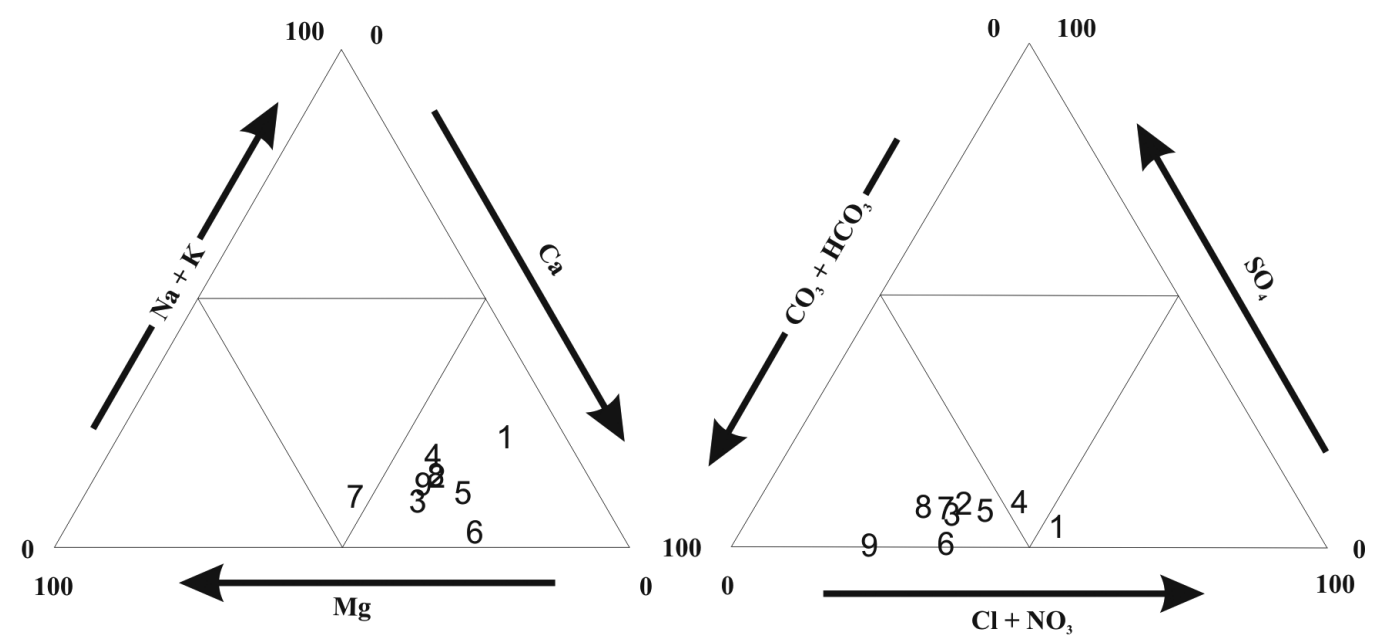

Figure 5 - The chemical data for surface waters from Meio Stream watershed plotted on a partial standard Piper (1944) diagram. 1, 4, 5, 7 and 8 -Meio Stream; 2 -Constantino Creek; 3 -Invernada Creek; 6 -Jequitibá Creek; 9 -Taquari Creek.

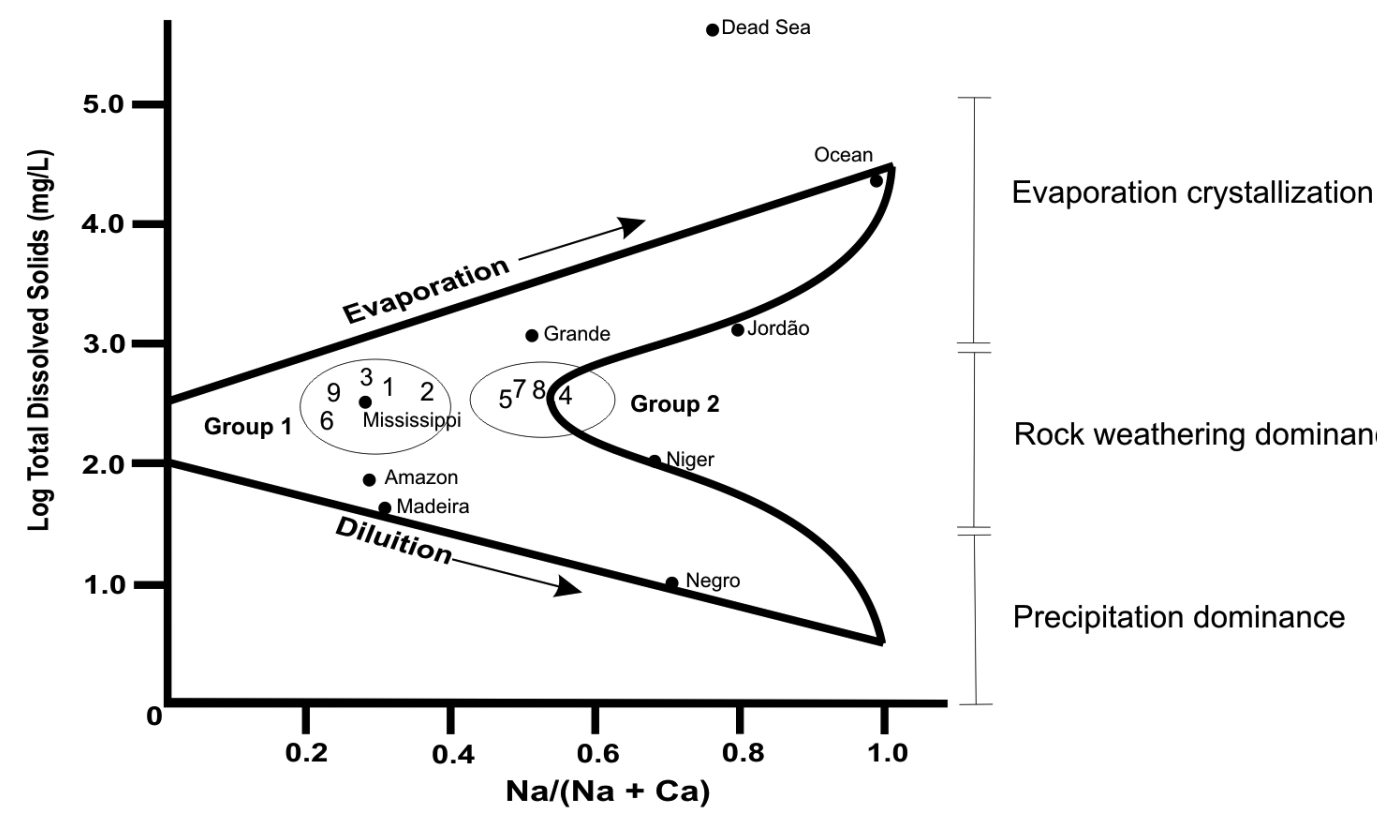

Figure 6 - The chemical data for surface waters from Meio Stream watershed plotted on a standard Gibbs (1970) diagram. The data for some rivers are from Berner and Berner (1987) and Silveira (1998). 1, 4, 5, 7 and 8 -Meio Stream; 2 -Constantino Creek; 3 -Invernada Creek; 6 -Jequitibá Creek; 9 -Taquari Creek. 
hydrochemical facies. $\mathrm{Ca}^{2+}$ dominates the surface waters, whereas the Meio Stream near the mouth (P7) has no dominant cation. In terms of anions, $\mathrm{HCO}_{3}^{-}$dominates the surface waters, whereas the Meio Stream after Leme city (P4) has no dominant anion and near the spring (P1) is $\mathrm{Cl}^{-}-\mathrm{NO}_{3}^{-}$dominated. Thus, in general, the surface waters from Meio Stream are dominantly a $\mathrm{Ca}^{2+}-\mathrm{HCO}_{3}-$ type, as also verified for Madeira River - Rondônia State, Brazil (Silveira, 1998), Piedmont Streams - Georgia, United States (Rose, 2002), Jaboatão River - Pernambuco State, Brazil (Souza and Tundisi, 2003), Lake Waco watershed - Texas, United States (Dworkin, 2003), Corumbataí River and tributaries São Paulo State, Brazil (Conceição and Bonotto, 2004) and Kumaun Lakes - Himalaya, India (Das, 2005).

Another chemical classification of surface waters was suggested by Gibbs (1970), where it is plotted the values of total dissolved solids (TDS) versus the relation $\mathrm{Na} /(\mathrm{Na}+\mathrm{Ca}$ ) (Fig. 6). The chemical composition of some waters from Meio Stream watershed (Group 1) is similar to Mississippi river (Berner and Berner 1987) in which the major ion chemistry is dominated by rock or mineral weathering (Gibbs 1970). The water samples P4, P5, P7 and P8 (all in Meio Stream) tend to form another group (Group 2) due to higher Na concentration, despite other sampling points do not follow this trend. The increase of $\mathrm{Na}$ in surface waters from Meio Stream may be a source of adverse effects on aquatic animal and plant life (affecting the osmosis process), as well contributing with residuals salts that can accumulate in the soil when these waters are applied in irrigated lands (Stoker and Seager 1976).

The annual flux of elements/compounds from Meio Stream watershed The Meio Stream (near the spring) and tributaries (Constantino, Invernada, Jequitiba and Taquari creeks) are situated in a region distant from major human influences, their headwater occur in different sedimentary rocks of the Paraná basin (Fig. 1). The mineralogical composition and $\mathrm{Na}, \mathrm{Ca}, \mathrm{K}$ and $\mathrm{Mg}$ concentration of sedimentary and igneous rocks from Paraná basin as well their outcrop area (Table 2) in- dicate that the rocks are sodium-depleted, as most of them are sedimentary rocks mainly comprising quartz, clay minerals and feldspar, which are relatively resistant to weathering processes (Toledo et al. 2000). The weighed mean values in rocks from Meio Stream watershed for the major cations decrease in the order $\mathrm{Ca}>$ $\mathrm{Mg}>\mathrm{K}>\mathrm{Na}$.

Pedro and Sieffermann (1979) considered that weathering is a form of incongruent dissolution, whereby: Primary minerals + attacking solution $=$ secondary minerals + leachate. The bedrock, climate, topography, biosphere and time are factors controlling the weathering processes (Martini and Chesworth 1992). The climate is a factor determining the type and alteration rate in an area. The temperature and precipitation are the most important climatic parameters. The bedrock composition also is important, due to the mineral constituents, texture and structure. The Meio Stream watershed is in a region where the climate causes moderate chemical weathering, with the predominance of monosiallitization (generation of clay minerals, kaolinite-type). This process occurs by partial hydrolysis of minerals from bedrock, with some of the Si remaining in the profile and $\mathrm{Na}, \mathrm{Ca}, \mathrm{K}$ and $\mathrm{Mg}$ being removed (Toledo et al. 2000). Some possible reactions involved in the weathering processes occurring in the Meio Stream watershed are shown in figure 7.

In order to estimate the annual flux of elements/ compounds $\left(\mathrm{t} / \mathrm{km}^{2} / \mathrm{yr}\right)$ from Meio Stream watershed, it is necessary to know the weighed mean concentration of cations/anions, area and discharge in water bodies (Moreira-Nordemann 1980 and 1984). The relevant data fot this study are area and discharge in Meio Stream - P1 $=1.58 \mathrm{~km}^{2}$ and $0.014 \mathrm{~m}^{3} / \mathrm{s}$, Constantino Creek - P2 $=6.59 \mathrm{~km}^{2}$ and $0.034 \mathrm{~m}^{3} / \mathrm{s}$, Invernada Creek - P3 $=14.54 \mathrm{~km}^{2}$ and $0.075 \mathrm{~m}^{3} / \mathrm{s}$, Jequitiba Creek - P6 $=9.97 \mathrm{~km}^{2}$ and $0.054 \mathrm{~m}^{3} / \mathrm{s}$ and Taquari Creek $-\mathrm{P} 9=$ $51.14 \mathrm{~km}^{2}$ and $0.265 \mathrm{~m}^{3} / \mathrm{s}$. Table 3 and figure 8 suggest that these water bodies possess different annual flux of cations/anions, where, in general, the Constantino and Invernada creeks are responsible for the higher annual flux of cations/anions.

Table 2 - Description, mineralogical data and $\mathrm{Na}, \mathrm{Ca}, \mathrm{K}$ and $\mathrm{Mg}$ concentration ( $\mathrm{mg} / \mathrm{g}$ ) of some stratigraphic units of the Paraná basin that crop-out in the Meio Stream watershed (Conceição and Bonotto, 2004).

\begin{tabular}{l|c|l|l|c|c|c|c}
\hline Group & $\%$ of area & Description & Mineralogical data & $\mathrm{Na}$ & $\mathrm{Ca}$ & $\mathrm{K}$ & $\mathrm{Mg}$ \\
\hline Tubarão & 6 & $\begin{array}{l}\text { Siltstones and } \\
\text { sandstones }\end{array}$ & $\begin{array}{l}\text { Quartz, albite, dolomite, microcline, } \\
\text { kaolinite, illite and calcite }\end{array}$ & 0.09 & 1.23 & 12.27 & 6.85 \\
\hline Passa Dois & 35 & $\begin{array}{l}\text { Mudstones and } \\
\text { siltstone }\end{array}$ & $\begin{array}{l}\text { Quartz, illite, kaolinite, dolomite, } \\
\text { microcline, albite, hematite and calcite }\end{array}$ & 0.19 & 163.52 & 6.92 & 55.11 \\
\hline $\begin{array}{l}\text { São Bento (Pirambóia } \\
\text { Formation) }\end{array}$ & 3 & Sandstones & Quartz and kaolinite & 0.05 & 3.09 & 7.49 & 7.75 \\
\hline $\begin{array}{l}\text { São Bento (Serra Geral } \\
\text { Formation) }\end{array}$ & 51 & Diabases & Quartz, magnetite, augite, labradorite & 1.19 & 67.81 & 7.32 & 20.30 \\
\hline \begin{tabular}{l} 
Recent deposits \\
\hline
\end{tabular} & 5 & Conglomerates & Quartz, kaolinite and gibbsite & 0.03 & 0.67 & 0.76 & 0.76 \\
\hline
\end{tabular}


Dissolution: Calcite $-\mathrm{CaCO}_{3} \longrightarrow \mathrm{Ca}^{2+}$ and $\mathrm{HCO}_{3}^{-}$

Dolomite $-\mathrm{CaMg}\left(\mathrm{CO}_{3}\right)_{2} \longrightarrow \mathrm{Ca}^{2+}, \mathrm{Mg}^{2+}$ and $\mathrm{HCO}_{3}^{-}$

Hydrolysis:

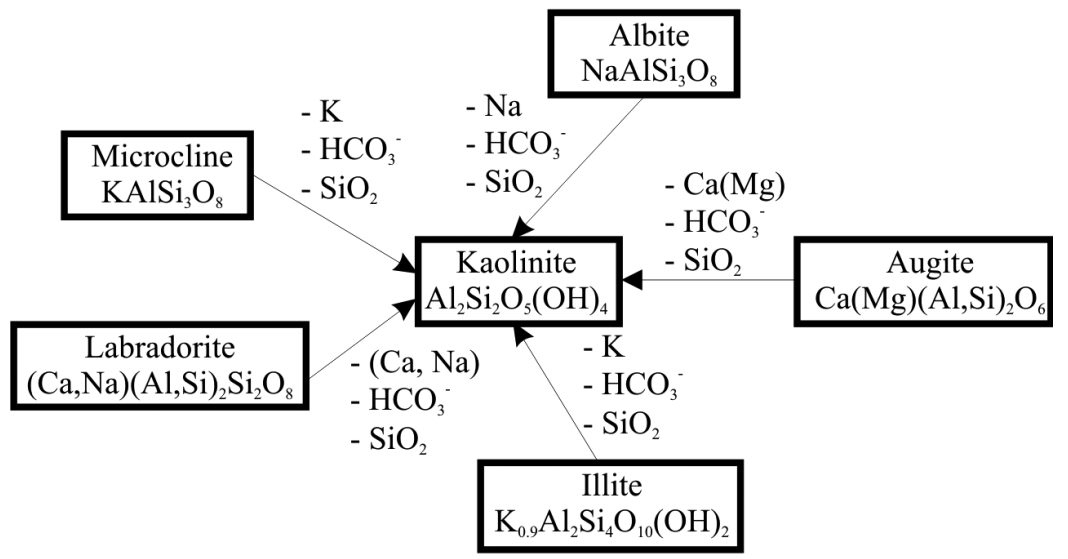

Figure 7 - Some possible weathering pathways of minerals in Meio Stream watershed.

Table 3 -The annual flux of cations/anions in water bodies situated in areas distant from major human influences at Meio Stream watershed.

\begin{tabular}{l|c|c|c|c|c|c|c|c|c|c|c}
\hline Sampling point & $\mathrm{Ca}^{2+}$ & $\mathrm{Mg}^{2+}$ & $\mathrm{Na}^{+}$ & $\mathrm{K}^{+}$ & $\mathrm{HCO}_{3}^{-}$ & $\mathrm{Cl}^{-}$ & $\mathrm{PO}_{4}^{3-}$ & $\mathrm{SO}_{4}^{2-}$ & $\mathrm{NO}_{3}^{-}$ \\
\hline & \multicolumn{7}{|c|}{$\left(\mathrm{t} / \mathrm{km}^{2} / \mathrm{yr}\right)$} \\
\hline P1 - Meio Stream (near the spring) & 1.20 & 0.13 & 0.79 & 0.79 & 3.36 & 2.29 & 0.13 & 0.60 & 0.61 \\
\hline P2 -Constantino Creek & 2.52 & 0.71 & 1.83 & 1.05 & 9.39 & 3.67 & 0.06 & 1.41 & 0.53 \\
\hline P3 - Invernada Creek & 2.05 & 0.64 & 1.02 & 0.59 & 7.94 & 2.88 & 0.05 & 0.89 & 0.42 \\
\hline P6 - Jequitiba Creek & 1.32 & 0.25 & 0.51 & 0.09 & 4.68 & 1.80 & 0.03 & 0.07 & 0.11 \\
\hline P9 - Taquari Creek & 0.67 & 0.23 & 0.50 & 0.25 & 2.47 & 0.40 & 0.01 & 0.00 & 0.16 \\
\hline
\end{tabular}
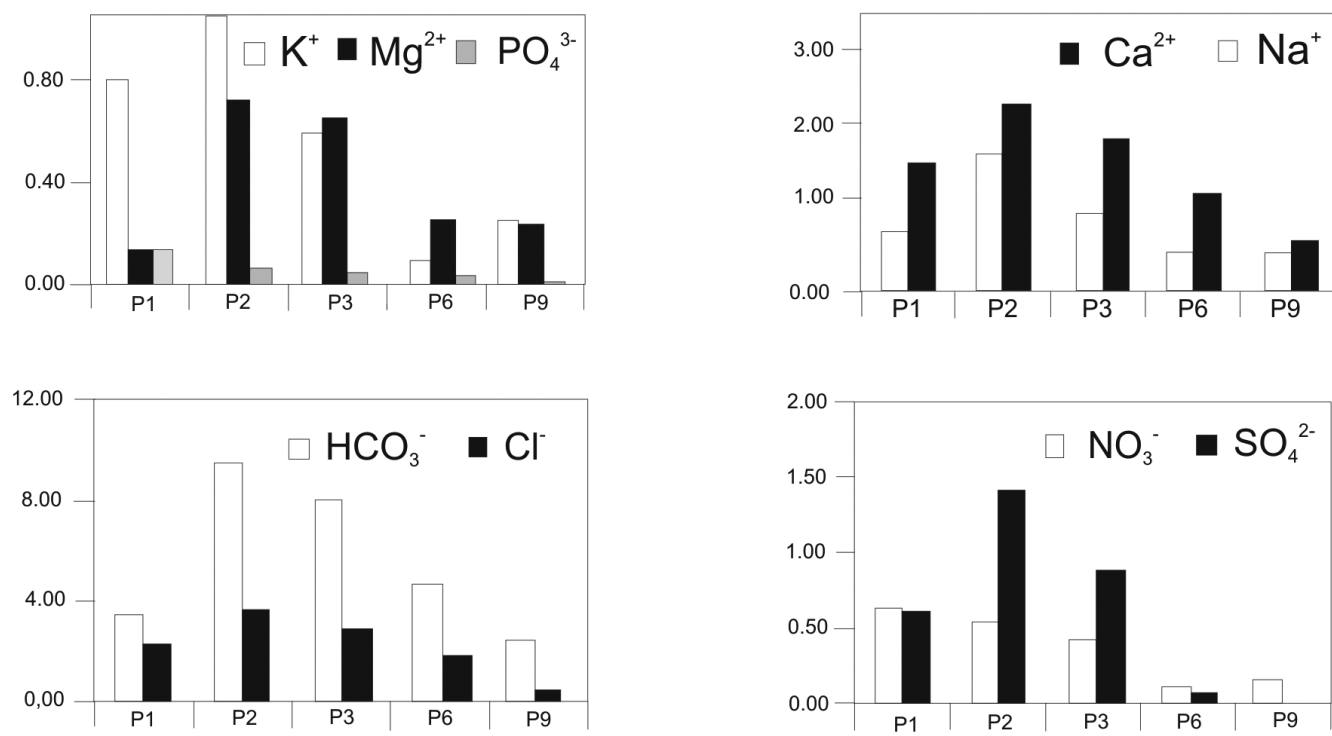

Figure 8 - Annual flux of cations/anions ( $\left.t / \mathrm{km}^{2} / \mathrm{yr}\right)$ for surface waters from Meio Stream watershed. P1 - Meio Stream; P2 - Constantino Creek; P3 - Invernada Creek; P6 Jequitibá Creek; P9 - Taquari Creek. 

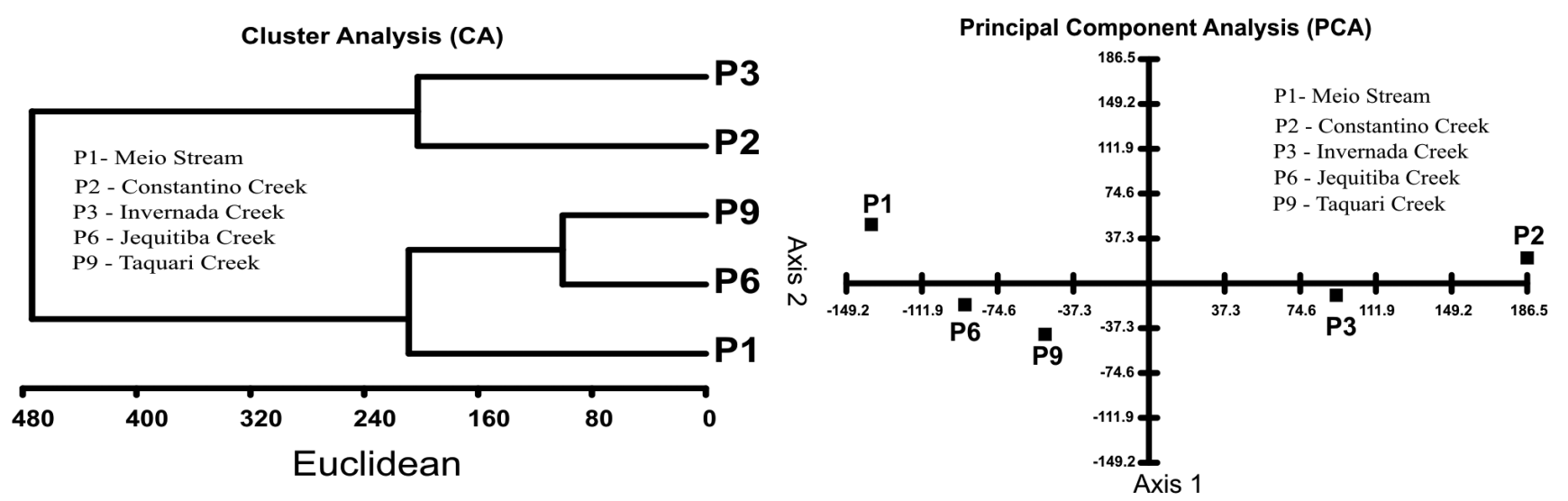

Figure 9 - Dendogram generated by cluster analysis (CA) and principal component analysis (PCA) applied to the ranked data for annual flux of cations/anions for surface waters from Meio Stream watershed. PI-Meio Stream; P2 -Constantino Creek; P3 -Invernada Creek; P6 -Jequitibá Creek; P9 -Taquari Creek.

Two different multivariate statistical approaches may also confirm the importance of Constantino and Invernada creeks. The first is the Cluster Analysis (CA) in $r$-mode (results cluster variables) that was performed using Ward's hierarchical agglomerative method (unweighed pair-group method, UPGM) and the squared Euclidean distance measured. Figure 9 shows the dendrogram obtained by the application of CA to the ranked data of annual flux of cations/anions (Table 3). The second statistical treatment applied to the same ranked data set was the Principal Components Analysis (PCA), which is an ordination method utilizing values and vectors from a variance-covariance matrix. The same information was also generated as shown in figure 9.

The annual flux of cations/anions indicate that much more material is supplied from Constantino (P2) and Invernada (P3) creeks, that are water bodies situated in areas with mudstones and siltstones (Passa Dois Group). These rocks present quartz, illite, kaolinite, microcline, albite, hematite and calcite in their mineralogical composition and the higher values of annual flux cations may be the result of the hydrolysis of albite $(\mathrm{Na})$, illite and microcline $(\mathrm{K})$ and dissolution of calcite $(\mathrm{Ca})$ and dolomite $(\mathrm{Ca}$ and $\mathrm{Mg}$ ). Jequitiba (P6) and Taquari (P9) creeks are dominated by weathering of rocks derived from São Bento Group (Serra Geral Formation - diabases) and the Na may be released by hydrolysis of labradorite and $\mathrm{Ca}$ and $\mathrm{Mg}$ by hydrolysis of labradorite and augite. The headwater at Meio Stream is located in an area with sandstones (São Bento Group - Pirambóia Formation) composed only by quartz and kaolinite, that are minerals resistant to weathering (Toledo et al., 2000).

In addition, the Meio Stream watershed does not contain volumetrically significant $\mathrm{Cl}^{-}, \mathrm{NO}_{3}^{-}, \mathrm{PO}_{4}^{3-}$ and $\mathrm{SO}_{4}^{2-}$ bearing minerals. Therefore, little natural inputs of these anions into rivers due to water-rock interactions are expected. Thus, the annual flux of $\mathrm{Cl}^{-}, \mathrm{NO}_{3}^{-}, \mathrm{PO}_{4}^{3-}$ and $\mathrm{SO}_{4}{ }^{2-}$ at Meio Stream and their tributaries should be mainly related to their inputs from the atmosphere. Vehicle traffic and fossil fuel burning (industrial activi- ties) are important and permanent sources of $\mathrm{SO}_{x}, \mathrm{NO}_{x}$ and $\mathrm{Cl}^{-}$emissions to the atmosphere. The $\mathrm{SO}_{\mathrm{x}}$ and $\mathrm{NO}^{x}$ compounds may be oxidized into $\mathrm{H}_{2} \mathrm{SO}_{4}-\mathrm{HNO}_{3}$ and removed by precipitation. Other sources of sulfate and nitrate are soil biological activities, especially in tropical regions, sugar cane burning and volatilization of $\mathrm{N}$ by phosphate fertilizers (Lara et al. 2001, Conceição and Bonotto 2004). In relation to $\mathrm{Cl}^{-}$, other possible sources could be related to marine influence (natural), incinerators, fertilizers, combustion or decomposition of organochlorine compounds and industries producing paper, like observed elsewhere (Négrel and Roy 1998, Sanusi et al. 1996). The inputs of phosphate to atmosphere may be attributed to anthropogenic sources, as the fertilizer-derived phosphate by agricultural soil dust with fertilizers in the wet period.

The instantaneous daily flux may be evaluated from the total solids concentration (TDS + TSS) in the Meio Stream, near the confluence with Mogi River (P7), and its daily discharge. This parameter is a func-

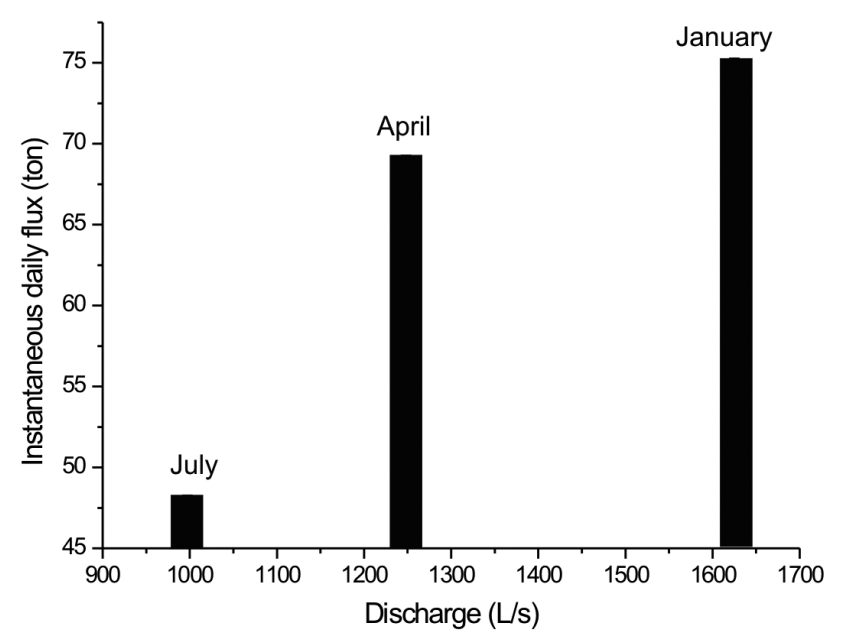

Figure 10 -Instantaneous daily flux versus discharge of sampling for surface waters from Meio Stream watershed (sampling point P7). 
tion of discharge, in accordance with most world rivers (Berner and Berner, 1996; Conceição and Bonotto, 2004), with the majority of the total solids load being transported during the summer (wet) months (Fig. 10). Using the weighed mean of total solids concentration $($ TDS + TSS $=577 \mathrm{mg} / \mathrm{L})$, the mean discharge in this same sampling point $\left(1.29 \mathrm{~m}^{3} / \mathrm{s}\right)$ and the area of this basin $\left(252 \mathrm{~km}^{2}\right)$, it is possible to calculate an annual removed material quantity corresponding to $93 \mathrm{t} / \mathrm{km}^{2} /$ yr, with $89 \mathrm{t} / \mathrm{km}^{2} / \mathrm{yr}$ due to TDS and $4 \mathrm{t} / \mathrm{km}^{2} / \mathrm{yr}$ due to TSS.

CONCLUSION This hydrochemical investigation held at Meio Stream watershed indicates alterations on its water quality. According to Brazilian standards, the Meio Stream is classified as Class 2. However, the absence of domestic waste treatment at Leme city has reduced the surface water quality, turning it to Class 4. All tributaries (Constantino, Invernada, Jequitiba and Taquari creeks) belong to Class 2. The dissolved oxygen concentration at Meio Stream, after Leme city, is lower than $5 \mathrm{mg} / \mathrm{L}$ (Class 2), indicating the need of settling a secondary wastewater treatment plant with minimum efficiency of $65 \%$. It was also verified that the removed material at Meio Stream watershed comes mainly from two sub-basins: Constantino and Invernada creeks, with the instantaneous flux being function of discharge, and the majority of dissolved load is transported during the wet summer months. For the appropriate management of the hydrological resources in the area studied, it is important that the several effluents sources are collected and treated before discharging into the water bodies. It is also important to constitute discussion groups' focusing the basin, as this is step is linked to environmental education initiatives.

Acknowledgements The authors thank Dr. André Henrique Rosa and Dr. Osmar Sinelli for their general help during the development of this investigation. Faculdades COC (Ribeirão Preto) are also thanked for the institutional and operational support in this study.

\section{References}

Ahipathy M.V., Puttaiah E.T. 2006. Ecological characterization of Vrishabhavathy River in Bangalore (India). Environmental Geology, 49:1217-1222.

Almeida F.F.M. \& Melo M.S. 1981. A bacia do Paraná e vulcanismos Mesozóicos. In: F.F.M. Allmeida, Y. Hasui, W.L Ponçano, A.S.L. Dantas, C.D.R. Carneiro, M.S. Melo, C.A. Bistrichi. (eds.) Mapa Geológico do Estado de São Paulo. São Paulo, IPT, escala 1:500.000.

APHA American Public Health Association. 1995. Standard methods for the examination of water and wastewater. $19^{\text {th }}$ ed, Byrd Prepress Springfield.

Barth F.T. 1999. Aspectos institucionais do gerenciamento de recursos hídricos. In: A. Rebouças, C.B. Braga, J.G. Tundisi (eds.) Águas doces no Brasil. São Paulo, Escrituras Editora, p. 565-599.

Berner E.K. \& Berner R.A. 1987. The global water cycles: geochemistry and environment. New Jersey, Prentice Hall, 397p.

Berner E.K., Berner R.A. 1996. Global environment. Water, air and geochemical cycles. New Jersey, Prentice Hall, $367 \mathrm{p}$.

Braga B., Hespanhol I., Conejo J.G.L., Barros M.T.L., Spencer M., Porto M., Nucci N., Juliano N., Eiger S. 2002. Introdução à Engenharia Ambiental. São Paulo, Prentice Hall, 305p.

CONAMA Conselho Nacional do Meio Ambiente. 2005. Resolução CONAMA n $n^{\circ} 357$ de 17 de março de 2005. IBAMA.

Conceição F.T. \& Bonotto D.M. 2002. Relações hidroquímicas aplicadas a avaliação da qualidade de água e diagnóstico ambiental na bacia do Rio Corumbataí (SP). Geochimica Brasiliensis, 16(1):1-21.

Conceição F.T. \& Bonotto D.M. 2004. Weathering rates and anthropogenic influences in a sedimentary basin, São Paulo State, Brazil. Applied Geochemistry, 19(4):575-
591.

Costa A.T., Nalini Jr H.A., Lena J.C., Friese K., Mages M. 2003. Surface water quality and sediment geochemistry in the Gualaxo do Norte basin, eastern Quadrilátero Ferrífero, Minas Gerais, Brazil. Environmental Geology, 45:226-235.

DAEE Departamento Autônomo de Águas e Energia Elétrica. 2005. Disponível em: http://www.sirgrh.sp.gov.br. Acesso em 20/11/2005.

Danelon O.M. \& Moreira-Nordemann L.M. 1991. Natural and anthropogenic occurrence of $\mathrm{Cl}^{-}, \mathrm{NO}_{3}^{-}, \mathrm{NH}_{4}^{+}$and $\mathrm{SO}_{4}{ }^{2-}$ at Quilombo River Basin (Cubatão - SP). Revista Brasileira de Geociências, 21(1):96-101.

Das B.K. 2005. Environmental pollution impacts on water and sediments of Kumaun lakes, lesser Himalaya, India: a comparative study. Environmental Geology, 49:230239.

Dworkin S.I. 2003 The hydrogeochemistry of the Lake Waco drainage basin, Texas. Environmental Geology, 45:106114.

EMBRAPA Empresa Brasileira de Pesquisa Agropecuária. 1999. Sistema Brasileiro de Classificação de Solos. EMBRAPA, 412p.

Esteves F.A. 1988. Fundamentos de Limnologia., Rio de Janeiro, Interciência/Finep, 602p.

Garrels R.M., Mackenzie F.T. 1967. Origin of the chemical composition of some springs and lakes. In: W. Stumm (Chaurman) Proc. Symp. equilibrium concepts in natural waters systems. Advances in Chem. Ser., 67, American Chemical Society, Washington, p.222-242.

Gibbs R.J. 1970. Mechanisms controlling world water chemistry. Science, 170:1088-1090.

Hach 1992. Water Analysis Handbook. 2ed Edition. Loveland, Hach Company, 658p.

IBGE Instituto Brasileiro de Geografia e Estatística. 2000. 
Censo Demográfico. Disponível em: http://www.ibge. gov.br. Acesso em: 20/11/2005.

IPT Instituto de Pesquisa Tecnológica do Estado de São Paulo. 1981. Mapa Geológico do Estado de São Paulo. São Paulo, IPT, escala 1:500.000.

Joshi B.K. \& Kothyari B.P. 2003. Chemistry of perennial springs of Bhetagad watersehd: a case study from central Himalayas, India. Environmental Geology, 44:572-578.

Keller E.A. 2000. Environmental Geology. $8^{\text {th }}$ ed., PrenticeHall, 564p.

Lara L.B.L.S., Artaxo P., Martinelli L.A., Victoria R.L., Camargo P.B., Krusche A., Ayres G.P., Ferraz E.S.B., Ballester M.V. 2001. Chemical composition of rainwater and anthropogenic influences in the Piracicaba river basin, southeast Brazil. Atmospheric Environment, 35:4937-4945.

Lima E.B.N.R. 2001. Modelagem integrada para gerenciamento da qualidade da água na bacia do Rio Cuiabá. Tese de Doutoramento, Universidade Federal do Rio de Janeiro, 184p.

Maier M.H. 1977. Estudo da variação sazonal das condições físicas e químicas ao longo de um trecho do Rio MogiGuaçu - Cachoeiras de Emas, Estado de São Paulo. São Carlos, Dissertação de Mestrado, UFCAR, 140p.

Martini I.P. \& Chesworth W. 1992. Weathering, soils and paleosols. Amsterdam, Elsevier, 618p.

Moreira-Nordemann L.M. 1980. Use of ${ }^{234} U /{ }^{238} U$ disequilibrium in measuring chemical weathering rate of rocks. Geochim. Cosmochim. Acta, 44:103-108.

Moreira-Nordemann L.M. 1984. Salinity and weathering rate of rocks in a semi-arid region. Journal. Hydrol., 71:131147.

Négrel P. \& Roy S. 1998. Chemistry of rainwater in the Massif Central (France): a strontium isotope and major element study. Appl. Geochem., 13:941-952.

Nogueira V.P. 1991. Qualidade de água em lagos e reservatórios. In: S.M. Porto, R.W. Cleary, R.M. Coimbra, S. Eiger, S.J. Luca, V.P.O. Nogueira, F.A. Porto (eds.) Hidrologia Ambiental. São Paulo, EDUSP, 168-208.

Oliveira J.B., Menk J.R.F., Barbieri C.L., Rotta C.L., Tremocold W. 1982. Mapa de Solos do Estado de São Paulo: Região de Araras. Escala 1:100.000. Boletim Técnico do Instituto Agronômico de Campinas 71, 180p.

Pedro G. \& Sieffermann G. 1979. Weathering of rocks and formation of soils. In: F.R. Siegel (ed.) Review in Modern Problems of Geochemistry. UNESCO, p. 39-54 .

Penteado M.M. 1976. Geomorfologia do setor centro-ocidental da "Depressão Periférica" no Estado de São Paulo. Séries Teses e Monografias, 22, IGEOG/USP, 86p.

Piper A.M. 1944. A graphic procedure in the geochemical interpretation of water-analyses. Trans. Amer. Geophysical
Union, 25:914-928.

Rose S. 2002. Comparative major ion geochemistry of Piedmont streams in the Atlanta, Georgia region: possible effects of urbanization. Environmental Geology, 42:102113.

Sanusi A., Wortham H., Millet M., Mirabel P. 1996 Chemical composition of rainwater in eastern France. Atmospheric Environment, 30:59-71.

Sawyer C.N., McCarty P.L., Parkin, G. F. 2000. Chemistry for sanitary engineers. $4^{\circ}$ ed, New York, McGraw-Hill, $634 \mathrm{p}$.

Seager J. 1993. Statutory water quality objectives and river water quality. Journal of the Institution of Water and Environmental Management, 7:556-563.

Silveira E.G. 1998. Mobilidade do mercúrio e outros elementos no Rio Madeira (RO). Rio Claro, Tese de Doutorado, UNESP, 93p.

Souza A.D.G. \& Tundisi J.G. 2003. Water quality in watershed of the Jaboatão River (Pernambuco, Brazil): a case study. Brazilian Archives of Biology and Technology, 46(4):711-721.

Stallard R.F. \& Edmond J.M. 1981. Geochemistry of the Amazon, I: Precipitation chemistry and the marine contribution to the dissolved load at the time of peak discharge. J. Geophys. Res., 86:9844-9858.

Stoker H.S. \& Seager S.L. 1976. Environmental chemistry: air and water pollution. Chicago, Scott, Foresman and Company, 231p.

Streeter H.W., Phelps E.B. 1925. A study of the pollution and natural purification of the Ohio River. Washington, Public Health Bulletin, 146, 75p.

Toledo M.C.M., Oliveira S.M.B., Melfi A. 2000. Intemperismo e formação do solo. In: W.Teixeira, M.C.M. Toledo, T.R. Fairchild, F. Taioli (eds.) Decifrando a Terra. São Paulo, Oficina de Textos, p.139-157.

USDA United States Department of Agriculture. 1999. Soil Taxonomy: A basic system of soil classification for making and interpreting soils surveys. $2^{\circ}$ ed., Washington DC, US Department of Agricultural Soil Conservation Service, $754 \mathrm{p}$.

von Sperling M. 1996. Introdução à qualidade de água e tratamento de efluentes. $2^{\circ}$ ed., Belo Horizonte, Departamento de Engenharia Sanitária, Universidade Federal de Minas Gerais, 211p.

White A.F. \& Blum A.E. 1995. Effects of climate on chemical weathering in watersheds. Geochim. Cosmochim. Acta, 59:1729-1747.

Manuscrito AE-082/2006 Submetido em 27 de março de 2007 Aceito em 30 de novembro de 2007 